\title{
Study the influence of nitrogen on rennin production by fungi Rhizomucor miehei using solid-state fermentation
}

\section{Houthail Al-Ahmad Al-Jammas ${ }^{*}{ }^{1}$, Hassan Al-Fathi ${ }^{1}$, Walid Al-Khalaf ${ }^{1}$ and Anton Taifor ${ }^{2}$}

${ }^{1}$ Department of Food Science. Agriculture Engineering Faculty. Al-Furat University, Deir ez-Zor. Syria.*Email: hothiel@hotmail.com. Based on a part of M.Sc. thesis of the first author.

${ }^{2}$ Department of Food Science. Agriculture Engineering Faculty. Damascus University. Syria.

\begin{abstract}
The effect of different nitrogen resources on the biosynthesis of milk clotting enzyme by Rhizmucor miehei was studied under solid state fermentation using wheat bran as base medium. Urea, peptone, albumin, casein, yeast extract were added with different concentrations (1\%-10\%). The response parameters were the ratio of milk clotting activity (MC) to proteolytic activity (PA) and protein content. The highest enzyme yield was achieved with casein at a rate of $2 \% \mathrm{w} / \mathrm{w}$ followed by $2 \%$ yeast extract, $1 \%$ albumin, $1 \%$ peptone, and $1 \%$ urea with values 5.6, 4.9, 4.2, 4, 3 $\mathrm{mg} / \mathrm{mL}$, respectively. Maximum enzyme activity (MCA/PA) was 50.4, 44.1, 37.8, 36, $27 \mathrm{SU}$ for casein, yeast extract, albumin, peptone, and urea, respectively.
\end{abstract}

Keywords: Rennin; Protease; Rhizomucor miehei; Solid state fermentation; Nitrogen.

\section{Introduction}

Rennet enzyme (rennin) is used in the manufacture of cheese, which is an acid protease, the effect of acid protease appears in the process of milk coagulation through two stages: in the first stage or enzymatic,
Received May 10, 2016

Accepted

May 30, 2016

Released June 30, 2016

Open Acess Full Text Article

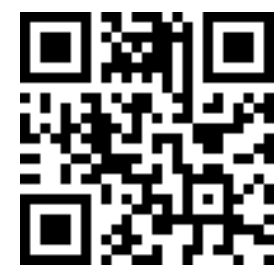

ORCIID

๑ $0000-0002-5072-1602$ Houthail Al-Ahmad AlJammas

(C) 0000-0003-3763-9636 Hassan Al-Fathi

(C) 0000-0002-7191-2256 Walid Al-Khalaf

(C) 0000-0001-5307-6445 Anton Taifor 
The increase in global cheese production in recent years in association with sharp decrease in calf rennet lead to search for alternative rennet substitute, many enzymes from plant and animal sources used as substitute and which showed in majority unsatisfactory properties, in addition to microbial substitute which has wide acceptable. Many of Microorganism give the enzyme rennin, but it is not suitable as substitutes for rennet since it should satisfy the following requirements; its proteolytic activity should be similar to calf rennet, should be able to curdle milk at the same conditions (calcium ion concentration, $\mathrm{pH}$ and temperature), effective coagulation of milk without undue hydrolysis of curd, proper flavor. It should not cause unwanted bacterial growth, absence of toxins and pathogens, should not cause unwanted antibiotic activity.

Studies have been conducted on some classes of bacteria and fungi, Aspergillus oryzae, Irpes lactis (Neelakantan et al., 1999; Ire et al., 2011; Nouani et al., 2011), Rhizopus sp (Sumantha et al., 2006; Gais et al., 2009).

The bacterial proteases is not suitable because of its high nonspecific proteolysis, studies recently focused on three fungal strains to produce microbial rennet Rhizomucor miehei, Endothia parastica, Rhizomucor pussilus (Thakur et al., 1990; Kazemi-Vaysari et al., 2002; Silveira et al., 2005; Farshad et al., 2013).

Currently most of the microbial rennet products in the world is produced using these three strains and sold under the trade names such as hannilase, rennilase, formase, miki, maryzme, modilase (Rhizomucor miehie), noury, meito, emporase (Rhizomucor pussilus), suparen, sure curd (Endoparthia parastica) (Neelakantan et al., 1999; Tiwari, 2003).

The protease of molds Rhizomucor miehei, Rhizomucor pussilus split the same peptide bonds, Phe 105-Met 106 which chymosin split in kappa casein, protease of Endothia parastica split the bond Ser104Phe105 (Tiwari, 2003).

Zygomicetes Rhizomucor miehei and Rhizomucor pussilus produce a coagulant with characteristics that are very similar to commercial rennet, producing high coagulation and production rates (Lima et al., 2008).

Rhizomucor pussilus extract is more proteolytic than calf rennet or Rhizomucor miehei extract, the clotting ability of its extract is three times of that in calf rennet, and not specific as Rhizomucor miehei extract, and tends to give hard curd because of its higher proteolytic activity and the curd tends to lose fat into whey, which make cheese yield lower, and produce bitter flavor in ripe cheese (Tiwari, 2003).

The protease of Rhizomucor miehei is the preferred substitute for calf rennet because of its specificity in splitting similar peptide bonds, high ratio of milk coagulation activity, identical calcium requirements and good cheese quality (Kazemi-Vaysari et al., 2002) and low incidence of bitter flavor in cheese curd (Tiwari, 2003).

The protease of Rhizomucor miehei is acid aspertate protease have a molecular weight of about 38,000 , the molecule consists of single peptide chain and contains about $6 \%$ carbohydrate, the enzyme is stable at $38{ }^{\circ} \mathrm{C}$ and $\mathrm{pH}$ values 3-6 with optimum $\mathrm{pH} 4.5$ for both stability and activity for denudated hemoglobin (Kazemi-Vaysari et al., 2002).

In general fermentation carried out by living cells can be using two types of fermentation, solid-state fermentation (SSF) and liquid state fermentation (LSF) or submerged fermentation (SF).

Submerged fermentations are usually carried out with a substrate which is either dissolved or remains suspended in an aqueous medium, and is suited for microorganisms such as bacteria that require high moisture (Subramaniyam, 2012), it consume substrate quickly so they need to add and replace substrate on an ongoing basis, it is expensive and needs more complex equipment.

Solid-state (substrate) fermentation (SSF) has been defined as the fermentation process occurring in the absence or nearabsence of free water. SSF has higher productivity compared to (SmF), using of raw materials and agro-industrial residues 
solves the pollution problem and reduce material cost. The lower water activity of the fermentation medium reduces the contamination risk especially by bacteria and yeast. Capital cost, energy expenditure and cost of downstream process are lower than SmF (Perez-Guerra et al., 2003; Krishna, 2005).

Consume the substrate slowly and gradually so it can be used for a long period of fermentation, do not need continuously mixing to bring homogeneity, ventilation processes simple, it does not require sophisticated technology, which need less energy and occupy less space (Al-Khafaji, 1990).

These advantages have made this system favorable in production of exoenzyme,mono-cell proteins, fermented foodstuff, toxins, organic acids, and some industrial chemicals, invertase, cellulose, lactase, aminoglycosides, pectinase and fungal protease.

In biotechnological processes, natural raw material, or recyclable waste material such as lignin, bran, wheat flour, rice flour, cotton, yeast extract, soy powder, beet molasses, starch, and cellulose are widely used as substrate. Wheat bran is a good choice for industrial production of enzymes. It is contains $65 \%$ carbohydrate, $16 \%$ protein, phosphate, calcium, iron, copper, magnesium, phosphate, potassium, sodium, zing, chlorine, lipids and vitamins B1, B2, B3, E, K (USDA, 2015) and is exclusively suitable for use in production of fungal enzymes (Singhania et al., 2010).

Some of the nutrients may be available in sub-optimal concentrations, or even absent in the substrates. In such cases, it would become necessary to supplement them externally with these.

The a viability of nitrogen in sufficient quantities is necessary to achieve the rapid growth of microorganism in all phases of growth, $15 \%$ of the dry mass of mycelium in filamentous fungi consists of nitrogen (Corbett, 1980), molasses, corn steep liquor, whey powder, soy flour, and yeast extract uses as raw materials rich in nitrogen added to the fermentation medium (Papagiani, 2004).
In this paper we studied the effect of supplying fermentation medium with deferent nitrogen resources; Urea, peptone, albumin, casein, yeast extract on biosynthesis of protease by fungi Rhizomucor miehei under solid state fermentation.

\section{Materials and methods}

Microorganism: Fungal strain in this study was Rhizomucor miehei ECC 841 (NRRL 3420) was obtained from Cairo MIRCEN - Faculty of Agriculture, Ain Shams University. It was maintained on (PDA) slants and stored in refrigerator at $4{ }^{\circ} \mathrm{C}$ for further use.

Inoculation medium: molds were inoculated in roux flask contains $100 \mathrm{~mL}$ (PDA), and incubate for 4 days at $25-30{ }^{\circ} \mathrm{C}$, the inoculum prepared by scratching with the existence of $200 \mathrm{~mL}$ sterilized distilled water. Concentration of spore suspension was determined by counting on an advanced Neubauer Counting chamber and then was used for the inoculation of the culture medium.

Fermentation medium: wheat bran was used as base material, acidic salt mineral solution $(100 \mathrm{~mL})$ was preparing containing in $(\mathrm{g} / \mathrm{L}) ; \mathrm{ZnSO}_{4} .7 \mathrm{H}_{2} \mathrm{O}: 0.07$ : $\mathrm{MgSO}_{4} .7 \mathrm{H}_{2} \mathrm{O}: 0.07: \mathrm{CuSO}_{4} .7 \mathrm{H}_{2} \mathrm{O}: 0.07$ : $\mathrm{FeSO}_{4}: 0.09 ; 0.2 \mathrm{~N} \mathrm{HCl}, 10 \mathrm{~mL}$ of this solution was distilled to $1 \mathrm{~L}$ and $60 \mathrm{~mL}$ of it was used to moisten $100 \mathrm{~g}$ of wheat bran (Thakur, 1990), $20 \mathrm{~g}$ of moist wheat bran was distributed in $250 \mathrm{~mL}$ Erlenmeyer flask, and autoclaved for $20 \mathrm{~min}$ at $121{ }^{\circ} \mathrm{C}$. After cooling flasks were inoculated with spore suspension with ratio $6_{10} / g$. and incubate at $40{ }^{\circ} \mathrm{C}$, for 4 days.

Optimizing nitrogen source: Urea, peptone, albumin, casein, yeast extract were added with concentrations (1\%-10\%), to determine the optimal source and concentration.

Enzyme extraction: After incubation period, the $100 \mathrm{~mL}$ of distilled water were added under shaking at $200 \mathrm{rpm}$ 
for $1 \mathrm{~h}$ at $4-10{ }^{\circ} \mathrm{C}$. The extract were filtered through (what man paper no. 1), the filtrate obtained was centrifuged at $6000 \mathrm{rpm}$ for $20 \mathrm{~min}$ at $4{ }^{\circ} \mathrm{C}$. The supernatant was used as crude enzyme source.

Protein content: was determined according to the method of Lowry, 1951).

\section{Enzyme activity.}

Milk clotting activity (MCA): MCA was determined according to the method of Arema et al. (1970).

Proteolytic activity (PA): was determined according to the method of Kunitz (1947).

\section{Results and discussion}

The main role of protease production is to degradation of complex proteins to simple composition protein easy consumed through cell (Rao et al., 1998).

The importance of nitrogen source showed in Figures 1 and 2, casein has increased enzyme production, the enzyme yield and enzyme activity has increased with adding casein and the higher value was at the concentration of $2 \%$, adding casein with higher concentrations resulted in decreased in both protein content and enzyme activity.

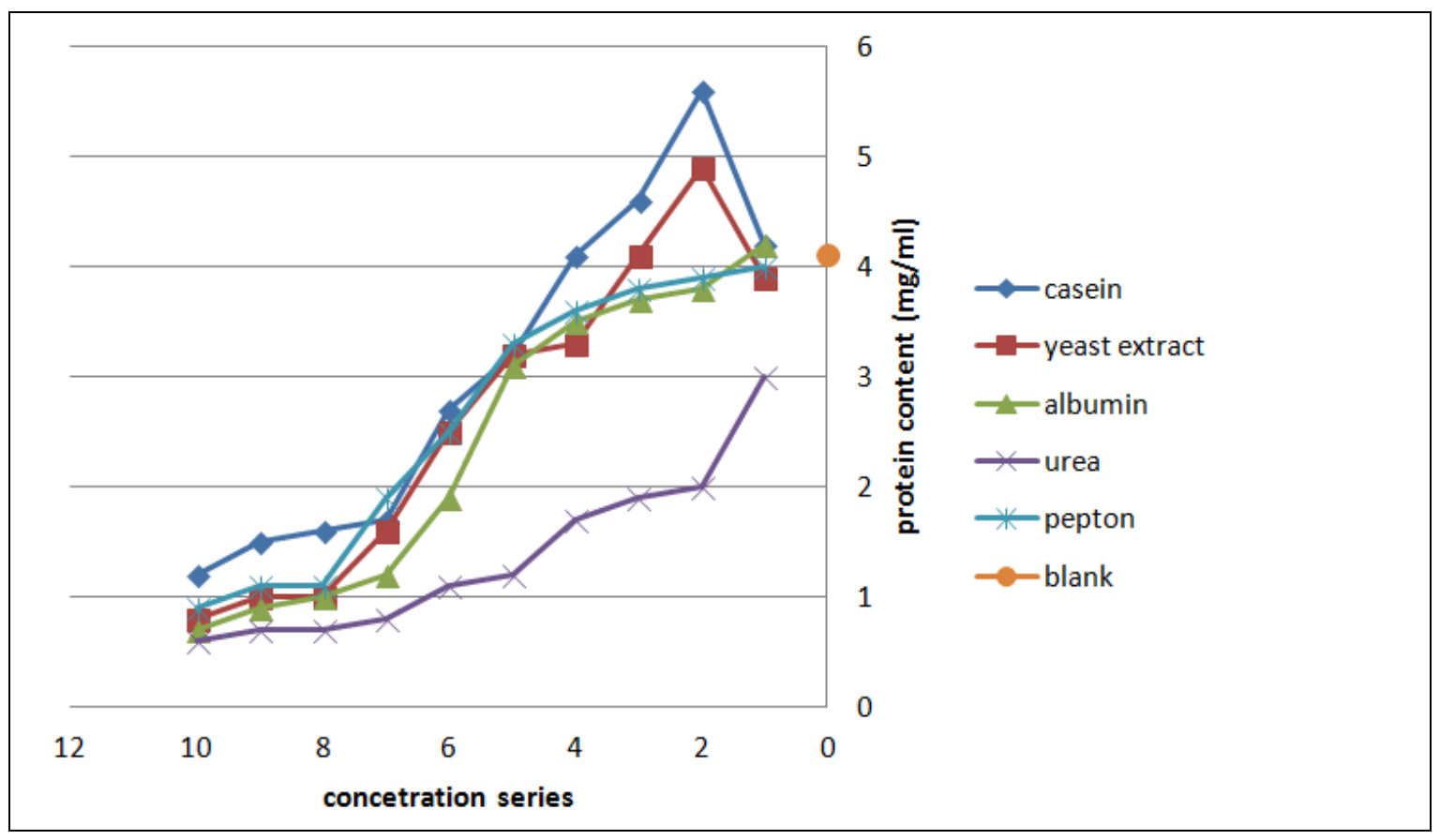

Figure 1. The effect of nitrogen concetration on protease production.

Fungi Rhizomucor miehei can exploit various nitrogen sources for the production of protease, addition of yeast extract up to $2 \%$ also increased protein content and enzymatic activity, addition yeast extract in (2\%-4\%) rates did not cause any increase in the yield or activity of the enzymes.

The continuing addition led to a decrease in both content and enzymatic activity and reached the lowest value at the rate $10 \%$.

As shown in Figures 1 and 2, albumin and peptone has less effect on protease production and the enzyme activity.

When urea were added to the medium, the enzyme yield and the enzyme activity were lower than the control. 


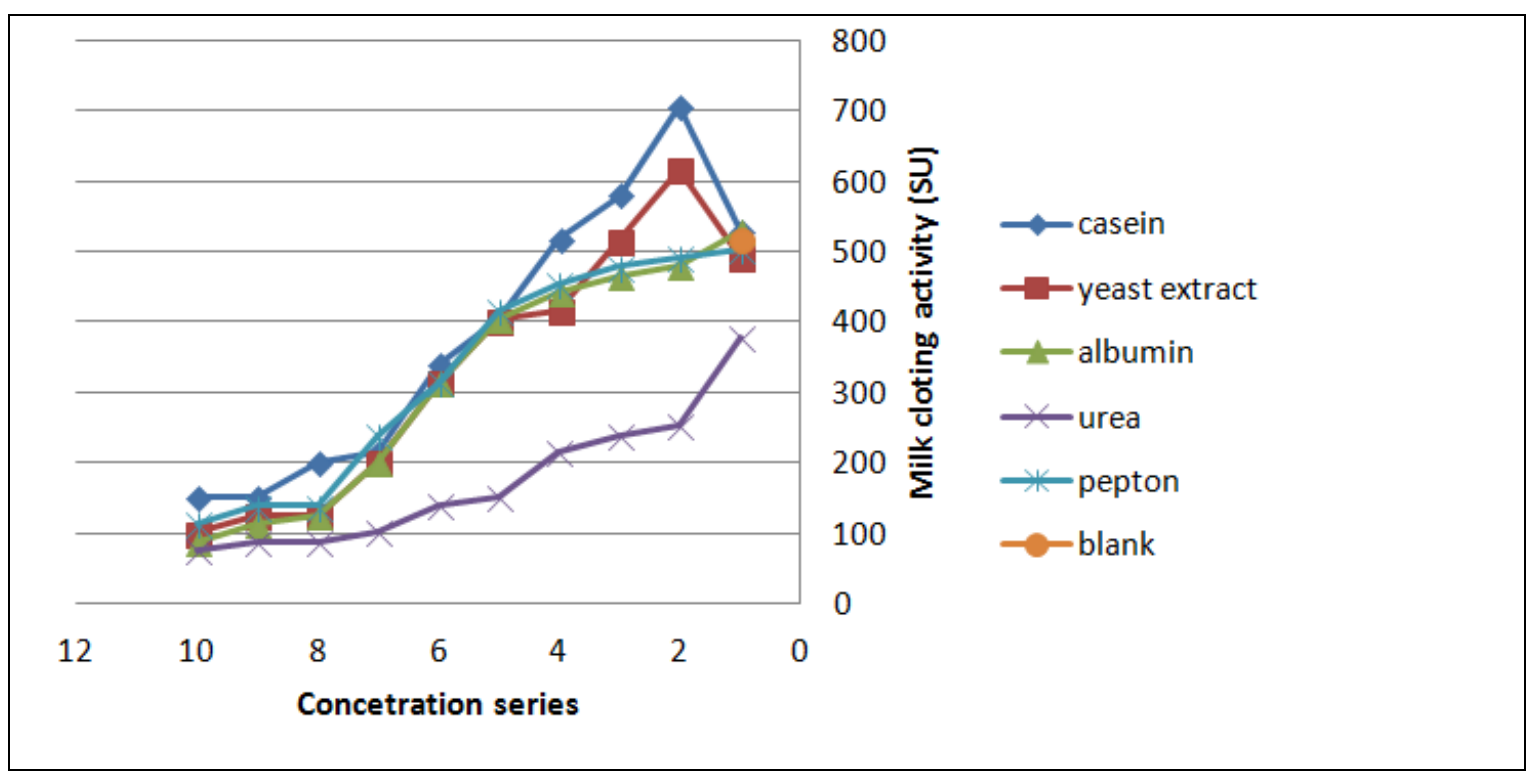

Figure 2. Effect of nitrogen source on milk cloting activity.

The variation in the production of protease according to the various nitrogen sources may be due to several reasons, including the difference in the physical and chemical nature of the nitrogen source, and it is one of the factors affecting microorganism growth and producing enzymes, especially in mediums with heterogeneous nature such as wheat bran, and the most important physical factors which is the surface area exposed to the microorganism reaction and material porosity and size of substrates (Nigam and Singh, 1994).

The chemical factors affecting the production of proteases is the nature of the of the constituent materials of the nitrogen source, whether simple or complex, in addition to the difference in the type and proportions of organic material in the source especially nitrogen, casein contains nitrogen by $15.9 \%$ (USDA, 2015), yeast extract contains nitrogen by $11 \%$ (Sigma Aldrich data base), peptone contains 10\% nitrogen (Kurbanoğlu and Algur, 2002). Khademi et al. (2013) referred that inorganic sources has no effect on enzyme yield. Or is likely to fungi Rhizomucor miehei produces several types of protease that nitrogen source can stimulates.

The reason for the low secretion and enzymatic activity as a result of increasing the concentration of nitrogen source may explains that Encoded genes necessary for nitrogen consumption enzymes normally regulated by mechanisms of stimulation or specialized induction are subject to major control mechanism known (nitrogen metabolite repression). According to this mechanism genes expressed at high levels at the demand conditions of nitrogen only, but with the existence of ready and preferred sources of nitrogen it leads to give a signal to stop gene expression of catabolic enzymes (Marzluf, 1997).

Thus can keeping most closely associated nitrogen sources even preferred or available sources consumption (Berger et al., 2008).

Larcher et al. (1996) illustrate the reduction in protease production by Scedosporium apiospermum with addition of high concentrations of peptone that the free amino acids released by hydrolysis of this high quantity of peptone may cause enzyme repression. 


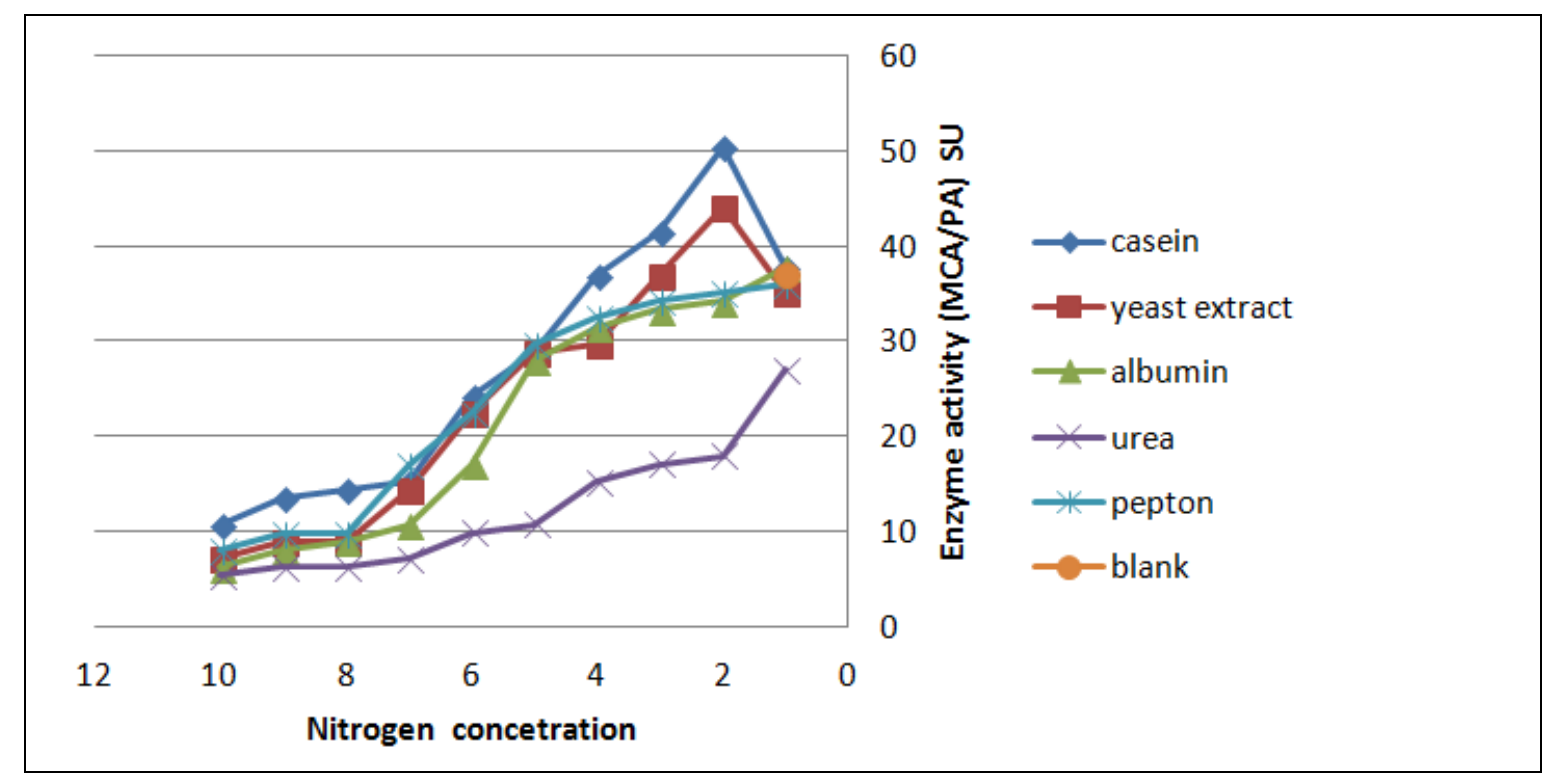

Figure3. The efect of nitrogen source on enzyme activity.

It seems that this phenomenon is widespread in fungi, especially filamentous fungi, as in the genus Aspergillus (Bouchara et al., 1993) and Rhizopus (Schindler et al., 1983).

Similar findings have been reported by other workers (Silveira et al., 2005; Foda et al., 2013; Khademi et al., 2013).

\section{Conflict of interest statement}

Authors declare that they have no conflict of interests.

\section{Conclusion}

Nitrogen has an important role in protease production, casein showed to be the best source of nitrogen, supplement medium with $2 \%(\mathrm{w} / \mathrm{w})$ casein lead to the highest enzyme yield and enzyme activity with values $(5.6 \mathrm{mg} / \mathrm{mL}, \quad 50.5 \mathrm{SU})$, respectively, compared to $4.9 \mathrm{mg} / \mathrm{mL}, 44.1$ $\mathrm{SU}, 4.2 \mathrm{mg} / \mathrm{mL}, 37.8 \mathrm{SU}, 4 \mathrm{mg} / \mathrm{mL}, 36 \mathrm{SU}$, $3 \mathrm{mg} / \mathrm{mL}, 27 \mathrm{SU}$, for $2 \%$ yeast extract, $1 \%$ albumin, $1 \%$ peptone, and $1 \%$ urea, respectively.

\section{References}

Al-Khafaji, Z. Biotechnology. Baghdad, Iraq: Institute of Genetic Engineering and Biotechnology, University of Baghdad, 1990.

Arima, K.; Yu, J.; Iwasaki, S. Milk-clotting enzyme from Mucor pussilus var. Lindt. Methods in Enzymology, v. 19, p. 446-460, 1970.

Berger, H.; Basheer, A.; Bock, S.; ReyesDominguez, Y.; Dalik, T.; Altmann, F.; Strauss, J. Dissecting individual steps of nitrogen transcription factor cooperation in the Aspergillus nidulans nitrate cluster. Mol. Microbiol., v. 69, no. 6, p. 1385-1398, 2008. http://dx.doi.org/10.1111/j.13652958.2008.06359.x

Bouchara, J.-P.; Larcher, G.; Joubaud, F.; Penn, P.; Tronchin, G.; Chabasse, D. Extracellular fibrinogenolytic enzyme of Aspergillus fumigatus: substrate-dependent variations in the proteinase synthesis and characterization of the enzyme. FEMS Immunol. Med. Microbiol., $\begin{array}{llll}\text { v. 7, no. 1, } & \text { p. 81-91, }\end{array}$ http://dx.doi.org/10.1111/j.1574695X.1993.tb00385.x

Corbett, K. Preparation, sterilization and design of media. British Mycological Symposium Series, v. 3, p. 25-41, 1980. 
Foda, M.; Moharam, M. E.; Ramadan, A.; ElBendary, M. A. Over production of milk clotting enzyme from Rhizomucor miehei through adjustment of growth under solid state fermentation conditions. Australian Journal of Basic and Applied Science, v. 6, no. 8, p. 579589, 2012. Available from: $<$ http://ajbasweb.com/old/ajbas/2012/August/57 9-589.pdf>. Accessed in: Feb. 24, 2016.

Gais, S.; Fazouane, F.; Mechakra, A. Production of milk clotting protease by Rhizopus stolonifer through optimization of culture conditions. World Academy of Science and Technology, v. 30, p. 1444-1448, 2009. Available from: $<$ http://waset.org/publications/15170/production -of-milk-clotting-protease-by-rhizopusstolonifer-through-optimization-of-cultureconditions>. Accessed in: Feb. 24, 2016.

Ire, F. S.; Okolo, B. N.; Moneke, A. A.; Odibo, F. J. C. Purification and characterisation of an acid protease from Aspergillus carbonarius. African Journal of Food Science, v. 5, no. 12, p. 695-709, 2011. Available from: <http://www.academicjournals.org/journal/AJF S/article-full-text-pdf/B8EE9EE10369>.

Accessed in: Feb. 24, 2016.

Kazemi-Vaysari, A.; Kheirolomoom, A.; Arjmand, M.; Habibollahi, M. Optimization of Mucor miehei rennin production and recovery. Scientia Iranica, v. 9, no. 1, p. 99-104, 2002. Available from: $<$ http://archive.scientiairanica.com/PDF/Articles /00000367/SI090114.pdf $>$. Accessed in: Feb. 24, 2016.

Khademi, F.; Abachi, S.; Mortazavi, A.; Ehsani, M. A.; Tabatabaei, M. R.; Malekzadeh, F. A. Optimization of fungal rennet production by local isolate of Rhizomucor miehei under solid substrate fermentation system. IOSR Journal of Pharmacy and Biological Science, v. 5, no. 2, p. 115-121, 2013.

Krishna, C. Solid-state fermentation systems: an overview. Crit. Rev. Biotechnol., v. 25, p. 130 , 2005

http://dx.doi.org/10.1080/07388550590925383

Kunitz, M. Crystalline soybean trypsin inhibitor: II. general properties. J. Gen. Physiol., v. 30, no. 4, p. 291-310, 1947. Available from: <http://jgp.rupress.org/content/30/4/291.long>. Accessed in: Feb. 24, 2016.

Kurbanoğlu, E. B.; Algur, Ö. F. Use of ram horn hydrolyste as a peptone for bacterial growth. Turk. J. Biol., v. 26, no. 2, p. 115-123, 2002. Available from: $<$ http://dergipark.ulakbim.gov.tr/tbtkbiology/arti cle/download/5000021818/5000022059>.

Accessed in: Feb. 24, 2016.

Larcher, G.; Cimon, B.; Symoens, F.; Tronchin, G.; Chabasse, D.; Bouchara, J.-P. A 33 kDa serine proteinase from Scedosporium apiospermum. Biochem. J., no. 315, p.119-126, 1996. Available from: $<$ http://www.ncbi.nlm.nih.gov/pmc/articles/PM C1217159/pdf/8670095.pdf $>$. Accessed in: Feb. 24, 2016.

Lima, C. J. B.; Cortezi, M.; Lovaglio, R. B.; Ribeiro, E. J.; Contiero, J.; Araújo, E. H. Production of rennet in submerged fermentation with the filamentous fungus Mucor miehei NRRL 3420. World Applied Science Journal, v. 4, no. 4, p. 578-585, 2008.

Lowry, O.; Rosebrough, N.; Farr, A.; Randall, R. Protein measurement with the folin phenol reagent. J. Biol. Chem., no. 193, p. 265-275, 1951. Available from: <http://www.jbc.org/content/193/1/265.long>. Accessed in: Feb. 24, 2016.

Marzluf, G. Genetic regulation of nitrogen metabolisim in the fungi. Microbiol. Mol. Biol. Rev., v. 61, no. 1, p. 17-32, 1997. Available from:

<http://mmbr.asm.org/content/61/1/17.long>. Accessed in: Feb. 24, 2016.

Neelakantan, S.; Mohanty, A. K.; Kaushik J. K. Production and use of microbial enzymes for dairy processing. Current Science, v. 77, p. 143-148, 1999. Available from: <http://www.iisc.ernet.in/currsci/jul10/articles2 2.htm>. Accessed in: Feb. 24, 2016.

Nigam, P.; Singh, D. Solid-state (substrate) fermentation system and their applications in biotechnology. J. Basic Microbiol., v. 34, no. 6, p. 405-423, 1994. http://dx.doi.org/10.1002/jobm.3620340607

Nouani, A.; Moulti-Mati, F.; Belbraouet, S.; Bellal, M. M. Purification and characterization of a milk-clotting protease from Mucor pusillus: method comparison. African Journal of Biotechnology, v. 10, no. 9, p. 1655-1665, 2011. Available from: <http://www.ajol.info/index.php/ajb/article/dow nload/92976/82388>. Accessed in: Feb. 24, 2016.

Papagianni, M. Fungal morphology and metabolite production in submerged mycelial processes. Biotechnol. Adv., v. 22, no. 3, p. 189-259, 2004. http://dx.doi.org/10.1016/j.biotechadv.2003.09.0 05

Pérez-Guerra, N.; Torrado-Agrasar, A.; LópezMacias, C.; Pastrana, L. Main characteristics 
and applications of solid substrate fermentation. Electron. J. Environ. Agric. Food Chem., v. 2, p. 343-350, 2003.

Rao, M. B.; Tanksale, A. M.; Ghatge, M. S.; Deshpande, V. V. Molecular and biotechnological, aspects of microbial proteases. Microbiol. Mol. Biol. Rev., v. 62, no. 3, p. 597635, $1998 . \quad$ Available from: $<$ http://www.ncbi.nlm.nih.gov/pmc/articles/PM C98927/pdf/mr000597.pdf>. Accessed in: Feb. 24, 2016.

Schindler, J.; Lehmann, R.; Pfeiffer, H.; Schmid, R. Extracellular acid protease of Rhizopus rhizopodiformis. In: Lafferty, R. M.; Maier, E.; Melsungen, B. B.; Melsungen, A. G. (Ed.). Enzyme Technology: III. Rotenburg Fermentation Symposium, 1982 SchloBhotel "Wtlhelmshohe" Kassel 22nd-24th September 1982. Berlin: Springer-Verlag, 1983. p. 69-77. http://dx.doi.org/10.1007/978-3-642-69148-5_8

Silveira, G. G.; Oliveira, G. M.; Ribeiro, E. J.; Monti, R.; Contiero, J. Microbial rennet produced by Mucor miehei in solid-state and submerged fermentation. Brazilian Archives of Biotechnology, v. 48, no. 6, p. 931-937, 2005. http://dx.doi.org/10.1590/S151689132005000800009

Singhania, R. R.; Pate, A.; Pandey A. The industrial production of enzymes. In: Soetaert, W.; Vandamme, E. J. (Ed.). Industrial biotechnology: sustainable growth and economic success. Weinheim: Wiley-VCH Verlag, $2010 . \quad$ p. 217-226. http://dx.doi.org/10.1002/9783527630233.ch5

Subramaniyam, R.; Vimala, R. Solid state and submerged fermentation for the production of bioactive substances: a comparative study. International Journal of Science Nature, v. 3, no. 3, p. 480-486, 2012. Available from: $<$ http://www.scienceandnature.org/IJSN_Vol3(3 )S2012/IJSN-VOL3\%283\%2912-1R.pdf>.

Accessed in: Feb. 24, 2016.
Sumantha, A.; Larroche, C.; Pandey, A. Microbiology and industrial biotechnology of food-grade proteases: a perspective. Food Technol. Biotechnol., v. 44, no. 2, p. 211-220, 2006. Available from: <http://www.ftb.com.hr/images/pdfarticles/2006 /April-June/44-211.pdf>. Accessed in: Feb. 24, 2016.

Thakur, M. S.; Karanth, N. G.; Nand, K. Production of fungal rennet by Mucor miehei. Appl. Microbial. Biotechnol., v. 32, no. 4, p. 409-413, 1990. http://dx.doi.org/10.1007/BF00903774

Tiwari, B. D. Microbial protein and its application in cheese making. In: Indian Council of Agricultural Research. (Ed.). Application of biotechnology in dairy and food processing. Karnal: Indian Council of Agricultural Research, 2003. p. 179-183. Available from: $<$ http://www.docfoc.com/application-ofbiotechnology-in-dairy-and-food-processing2003>. Accessed in: Feb. 24, 2016.

USDA - United State Department of Agriculture National. Agricultural Research Service. Nutrient database for standard reference. 2015. (Release 28). Available from: $<$ http://www.ars.usda.gov/Services/docs.htm?do cid=8964> . Accessed in: Feb. 24, 2016. 